\title{
Intravenous magnetic nanoparticle cancer hyperthermia
}

\author{
Hui S Huang \\ James $F$ Hainfeld \\ Nanoprobes, Yaphank, NY, USA
}

Video abstract

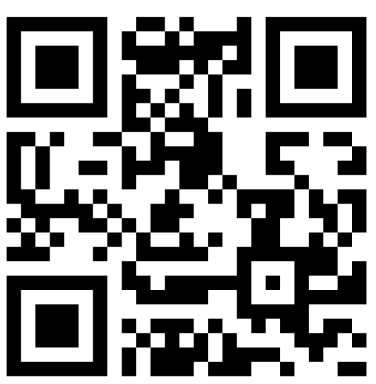

Point your SmartPhone at the code above. If you have a QR code reader the video abstract will appear. Or use: http://dvpr.es//48FPit
Correspondence: James F Hainfeld Nanoprobes, Inc, 95 Horseblock Rd, Unit I, Yaphank, NY, USA

Tel + I 63I 2059490 ext I05

Fax + I 63I 2059493

Email hainfeld@nanoprobes.com
This article was published in the following Dove Press journal:

International Journal of Nanomedicine

16 July 2013

Number of times this article has been viewed

Abstract: Magnetic nanoparticles heated by an alternating magnetic field could be used to treat cancers, either alone or in combination with radiotherapy or chemotherapy. However, direct intratumoral injections suffer from tumor incongruence and invasiveness, typically leaving undertreated regions, which lead to cancer regrowth. Intravenous injection more faithfully loads tumors, but, so far, it has been difficult achieving the necessary concentration in tumors before systemic toxicity occurs. Here, we describe use of a magnetic nanoparticle that, with a well-tolerated intravenous dose, achieved a tumor concentration of $1.9 \mathrm{mg} \mathrm{Fe} / \mathrm{g}$ tumor in a subcutaneous squamous cell carcinoma mouse model, with a tumor to non-tumor ratio $>16$. With an applied field of $38 \mathrm{kA} / \mathrm{m}$ at $980 \mathrm{kHz}$, tumors could be heated to $60^{\circ} \mathrm{C}$ in 2 minutes, durably ablating them with millimeter $(\mathrm{mm})$ precision, leaving surrounding tissue intact.

Keywords: magnetic nanoparticles, hyperthermia, cancer, alternating magnetic field, intravenous delivery

\section{Introduction}

Ferromagnetic material is composed of microscopic interacting domains. Once these domains are aligned by a field, they remain oriented and the material is magnetized. For magnetite, $\mathrm{Fe}_{3} \mathrm{O}_{4}$, the domain size is $15-80 \mathrm{~nm} .{ }^{1}$ Subdomain nanoparticles align and respond to a magnetic field, but when the field is removed, the thermal motion is high enough to randomly reorient them, leaving no residual magnetization. These magnetic materials are termed "superparamagnetic." The first superparamagnetic ferrofluids were formed by finely grinding magnetic material. For intravenous (IV) use, superparamagnetic iron oxide particles (or just "magnetic nanoparticles" [MNPs]) do not aggregate, thus avoiding emboli. MNPs heat up in an alternating magnetic field (AMF), either by physical rotation (the Brownian effect) or moving the magnetic moment without particle movement (the Néel effect). ${ }^{2}$

In 1957, Gilchrist et al first used magnetic particles to heat tissues with a $1.2 \mathrm{MHz}$ magnetic field. ${ }^{3}$ Application to hyperthermia treatments and cancer followed. ${ }^{4-6}$ Since then, many studies have ensued to harness this technology for potential clinical use (reviews ${ }^{7-12}$ ). In addition to direct tissue heating, MNPs can be incorporated into drug delivery systems that involve heat releasing the drug. ${ }^{13-17}$ For example, MNPs have been trapped either in the core or in between the lipid bilayer of thermosensitive liposomes and, on AMF heating, shown to release encapsulated drugs. ${ }^{13,18-20}$ A chain of three $20 \mathrm{~nm}$ MNPs were attached to loaded liposomes and shown to release doxorubicin and exhibit mouse tumor control over 17 days using an unusually low $10 \mathrm{kHz}$ field applied for 3 hours at a time. ${ }^{21}$ When positively charged cisplatin 
ionically bound to phosphate-starch coated MNPs was heated, it was shown to release the drug and kill cells. ${ }^{22}$ In another study, a thermosensitive polymer was layered onto MNPs covalently coupled to doxorubicin with an acid-labile hydrazine bond that showed release on heating with AMF and a $\mathrm{pH}$ of 5.3 (the $\mathrm{pH}$ of endosomes). ${ }^{23}$ Hydrophobic and hydrophilic drugs have also been encapsulated, via emulsification, with MNPs in a polyvinyl alcohol polymer that demonstrated drug release when heated with an AMF and mouse tumor control over 30 days. ${ }^{24}$ Oleic acid/Pluronic ${ }^{\circledR}$ coated MNPs were associatively loaded with daunorubicin and 5-bromotetrandrine and effectively treated tumors for 12 days after AMF heating - these were shown to decrease P-glycoprotein and Bcl-2 expression while increasing Bax and caspase-3 expression. which may assist in combating multidrug resistance. ${ }^{25}$ Gels incorporating MNPs implanted into tumors have also been developed. ${ }^{26}$ Much progress has also been made in developing better quality magnetic nanoparticles that: are constructed using high temperature crystallization; ${ }^{27}$ heat better; ${ }^{28,29}$ have different coatings, such as dextran, ${ }^{30,31}$ polyethylene glycol (PEG), ${ }^{32}$ dopamine, ${ }^{33}$ silanes, ${ }^{34}$ and gold $; 3,36$ have low Curie temperatures for heat control; ${ }^{37}$ and for liposomal encapsulation. ${ }^{17,38-40}$

Direct intratumoral injections of MNPs followed by induction heating has shown some benefit in controlling tumor growth. ${ }^{38,41-49}$ Direct intratumoral injection was used in the first MNP hyperthermia clinical trial treating a prostate cancer using a $100 \mathrm{kHz}$ machine designed for human patients, ${ }^{50}$ and later in human glioma trials ${ }^{51,52}$ which demonstrated safety and some benefit. Heating was obtained, but due to inhomogeneous MNP distribution, complete tumor eradication was not possible. Although direct intratumoral injections have the advantages of achieving high concentrations of MNPs and limiting systemic toxicity, they have the severe disadvantages of not generally covering tumors adequately, ${ }^{41,52}$ being invasive, and not being amenable to small metastatic tumor growths. In contrast, IV administration, although also not uniform, covers irregular tumor shapes more precisely, even small tumors (as has been shown with similar-sized gold nanoparticles ${ }^{53,54}$ ) and is minimally invasive. Although IV administration does not result in a homogeneous tumor loading, the distribution is more global and thorough rather than the punctate distribution from direct injections. ${ }^{55,56}$ Complete uniformity is not required, since heating will fill in by conduction or surround low concentration regions. More complete tumor treatment appears better attainable with IV distributions. Previous attempts to implement IV MNPs followed by AMF heating showed some efficacy but were not able to fully ablate tumors, as the required concentration was not reached in the tumors. ${ }^{57-59}$ From calculations, test tube experiments, and in vitro cell hyperthermia, it appears that $\sim 0.1 \%-0.4 \%$ iron by weight is required for adequate heating in a tumor. ${ }^{60,61} \mathrm{~A}$ barrier to this approach has been the toxicity of the MNPs at a level that achieves the required tumor loading after IV injection. Here, we present results attaining $0.19 \%$ iron in subcutaneous tumors after a nontoxic IV injection, enabling durable tumor ablation after AMF hyperthermia.

\section{Materials and methods MNPs}

A commercially available "biocompatible" type of magnetic nanoparticles was evaluated in these studies (catalog number 9900, Nanoprobes, Yaphank, NY, USA). Specific loss power (SLP) was measured by published methods. ${ }^{62}$ Briefly, $1.2 \mathrm{~mL}$ of a $2.1 \mathrm{mg}$ Fe/mL MNP solution was placed in an Eppendorf tube insulated with Styrofoam in the AMF $(980 \mathrm{kHz}, 38 \mathrm{kA} / \mathrm{m})$. A fiber-optic thermocouple was inserted to measure the temperature over time. Using the initial slope of heating, the SLP was calculated using the formula: $\mathrm{SLP}=(\mathrm{C} \times \mathrm{V}) / \mathrm{m} \times \mathrm{dT} / \mathrm{dt}$, where $\mathrm{C}$ is the volume-specific heat capacity of the sample $\left(\mathrm{C}_{\text {water }}=4185 \mathrm{~J} \mathrm{~kg}^{-1} \mathrm{~K}^{-1}\right), \mathrm{V}$ is the sample volume, and $\mathrm{m}$ is the mass of $\operatorname{iron}^{58}$ (not $\mathrm{Fe}_{3} \mathrm{O}_{4}$ or compound molecular weight). Typically, in 5.3 seconds, the temperature of the sample rose by $4.2^{\circ} \mathrm{C}$, whereas that of water alone rose by $0.2^{\circ} \mathrm{C}$. The heating rate of water alone was subtracted from the MNP sample heating rate. A small volume of water $(1.2 \mathrm{~mL})$ was used, since the heating coil was only one turn. Larger volumes would lead to averaging from regions having lower applied field.

\section{Electron microscopy}

Low-magnification transmission electron microscope images were taken with an FEI BioTwinG transmission electron microscope (Hillsboro, OR, USA). High-resolution lattice images and diffraction patterns were taken with a JEOL ARM200CF double-corrected S/TEM operating at $200 \mathrm{keV}$ (Tokyo, Japan). One microliter of $70 \mathrm{mg} \mathrm{Fe} / \mathrm{mL}$ purified iron particles in water was dispersed into $1 \mathrm{~mL}$ acetone. The solution $(50 \mu \mathrm{L})$ was applied to an ultrathin carbon film on holey carbon support film (400 copper mesh; Ted Pella, Redding, CA, USA) and air dried.

\section{Dynamic light scattering}

One microliter of $70 \mathrm{mg} \mathrm{Fe} / \mathrm{mL}$ purified iron particles in water was dispersed into $1 \mathrm{~mL}$ water, 0.2 -micron filtered, and 
measured with a 90Plus Particle Size Analyzer (Brookhaven Instruments, Holtsville, NY, USA). Results are reported here for lognormal intensity analysis and error as standard error of the mean.

\section{Tissue culture}

Murine squamous cell carcinoma SCCVII cells (American Type Culture Collection, Manassas, VA, USA) were grown in Gibco ${ }^{\circledR}$ Dulbecco's Modified Eagle Medium (Life Technologies, Carlsbad, CA, USA) supplemented with Gibco 10\% calf serum (Life Technologies) and Gibco Antibiotic-Antimycotic (Life Technologies). Cells were incubated at $37^{\circ} \mathrm{C}$ and $10 \% \mathrm{CO}_{2}$.

\section{Subcutaneous tumors}

SCCVII squamous cell carcinoma tumors were initiated by injecting 200,000 cells in a total volume of $50 \mu \mathrm{L}$ containing $50 \%$ Matrigel (Becton Dickinson, Franklin Lakes, NJ, USA) subcutaneously in the thighs of 8-10-week-old NCr nude mice (Taconic, Hudson, NY, USA). Tumors were treated with hyperthermia 10-11 days after implantation when they were $\sim 150 \mathrm{~mm}^{3}$. Mice were euthanized when tumors reached $1000 \mathrm{~mm}^{3}$. All animal studies were carried out in accordance with the Guide for the Care and Use of Laboratory Animals of the National Research Council of the National Academies. The protocol was approved by the Institutional Animal Care and Use Committee of the State University of New York at Stony Brook.

\section{Iron injections}

Iron nanoparticles were concentrated to $130 \mathrm{mg} \mathrm{Fe} / \mathrm{mL}$ in $80 \%$ phosphate-buffered saline (PBS) - $10 \mathrm{mM}$ phosphate buffer, $\mathrm{pH} 7.4,140 \mathrm{mM} \mathrm{NaCl}$ - and injected intravenously via a tail vein at $1.7 \mathrm{~g} \mathrm{Fe} / \mathrm{kg}$ body weight (bw).

\section{Maximum tolerated dose (MTD50)}

Three mice in each group were intravenously injected with 0.8, 1.7, 2.6, 3.4, 4.2, and 5.1 g Fe/kg MNPs. Body weights were monitored once per day over 2 weeks and once per week for 1 month. "MTD50" is here defined as the dose at which $50 \%$ of animals lost $>15 \%$ of their original body weight any time within 1 month.

\section{Pharmacokinetics}

Female NCr nude mice were subcutaneously implanted with SCCVII cells as described above. The animals were intravenously injected with MNPs (1.7 $\mathrm{g} \mathrm{Fe} / \mathrm{kg})$ once the tumors reached $\sim 0.15 \mathrm{cc}$ and three mice per time point were killed at various time points thereafter. Tissues were harvested, weighed, and analyzed for iron content. After subtraction of iron from control mice (without MNP injection), the means and standard error of the means were plotted. Six time points were assayed: 5 minutes, 1 hour, and 4, 8, 24, and 96 hours. Blood half-life was analyzed as a two-component decay with exponential fitting using a two-phase half-life model with Prism 5 software (GraphPad, La Jolla, CA, USA).

\section{Iron measurement}

To release iron, the tissues were first digested with a strong acid mixture of $1 \mathrm{M} \mathrm{H}_{2} \mathrm{SO}_{4}$ and $1 \mathrm{M} \mathrm{HNO}_{3}$ and heated to $60^{\circ} \mathrm{C}$. After tissues were mostly dissolved ( $\sim 30-40$ minutes $)$, $\mathrm{HCl}$ was added at 3:1 $\mathrm{HCl}: \mathrm{HNO}_{3}$ ratio. Triton X-100 (final $10 \%$ ) was also added to solubilize cell membranes.

Tissue iron content was measured by a colorimetric method adapted from Ceriotti and Ceriotti. ${ }^{64}$ Briefly, 4-(2-hydroxyethyl)1-piperazineethanesulfonic acid (HEPES) was added to the digested tissue samples to $0.1 \mathrm{M}$ and the $\mathrm{pH}$ adjusted to 3 with $10 \mathrm{~N} \mathrm{KOH}$. Ascorbic acid (final 10\%) was added to reduce the ferric ions to ferrous ions. Finally, FerroZine ${ }^{\mathrm{TM}}$ reagent (3-(2-Pyridyl)-5,6-diphenyl-1,2,4-triazine-p,p'-disulfonic acid monosodium salt hydrate; Sigma-Aldrich, St Louis, MO, USA) was added to the solution to form a purple-colored complex. The absorption was measured at $562 \mathrm{~nm}$ and compared with a standard curve. This method was further calibrated by the Nanotechnology Characterization Laboratory at the National Institutes of Health using inductively coupled plasma mass spectroscopy using a National Institute of Standards and Technology iron standard. The tissue iron concentration of mice without MNPs was subtracted from the MNP-injected mice tissue concentrations.

\section{Induction equipment}

A $10 \mathrm{~kW}$ induction heater with a single turn, $2.5 \mathrm{~cm}$ diameter coil operating at $980 \mathrm{kHz}$ and $38 \mathrm{kA} / \mathrm{m}$ (model SI-10KWHF, Superior Induction, Pasadena, CA, USA) was used for treatment, or alternatively model IMH5.0 (MSI Automation, Inc., Wichita, KS, USA). Field strength was measured with a twodimensional magnetic field probe (model 0015, $100 \mathrm{kHz}$ to $1 \mathrm{MHz}$, AMF Life Systems, Rochester, MI, USA).

\section{Hyperthermia treatment}

Mice were anesthetized intraperitoneally with ketamine $(100 \mathrm{mg} / \mathrm{kg}) / x y l a z i n e(8 \mathrm{mg} / \mathrm{kg})$ and positioned in a Plexiglas holder such that one leg extended downward through a $1 \mathrm{~cm}$ hole and this was anchored to a lower plate via dental floss loosely tied around the ankle. The holder was attached to a computer-controlled stepping motor (T-LS80-I; Zaber, Vancouver, $\mathrm{BC}$, Canada) that oscillated the mouse leg vertically through 
the center of the coil with a stroke of $25 \mathrm{~mm}$, encompassing the $\sim 6 \mathrm{~mm}$ tumors and surrounding tissue. The oscillation speed was $4 \mathrm{~mm} /$ second with a period of 6 seconds. The surface temperature of the tumor and surrounding skin was monitored using a FLIR SC300 series thermal camera (FLIR Systems, Wilsonville, OR, USA). Internal tumor temperatures were monitored with fiber-optic thermocouples (Reflex-4, Neoptix Canada, La Malbaie, QC, Canada) on some mice to determine the correlation between internal versus external temperatures. The mice legs were scanned in the AMF 24 hours after IV injection of MNPs. To monitor and limit normal tissue damage from heat conduction from the heated tumor into surrounding tissue, the field was applied until the skin $0.8 \mathrm{~cm}$ from the tumor edge reached $50^{\circ} \mathrm{C}$, which typically took $\sim 2$ minutes.

\section{Results}

We evaluated the properties and in vivo use of a newly available type of biocompatible magnetic particles with a core of $\mathrm{Fe}_{3} \mathrm{O}_{4}$ (magnetite) and a $2000 \mathrm{MW}$ PEG coating. Electron microscopy showed the iron oxide core to be $11.3 \pm 2.3 \mathrm{~nm}$ in size (Figure 1A). High-resolution imaging and the diffraction pattern were consistent with $\mathrm{Fe}_{3} \mathrm{O}_{4}$ cores (Figure $1 \mathrm{~B}$ and C). ${ }^{64}$ Dynamic light scattering indicated that the MNPs had a hydrodynamic diameter of $23.8 \pm 0.1 \mathrm{~nm}$ and a polydispersity of 0.087 . Their efficiency of heating in an AMF $(38 \mathrm{kA} / \mathrm{m}$, $980 \mathrm{kHz}$ ), characterized by SLP, was $754 \mathrm{~W} / \mathrm{g}(\mathrm{Fe})$. "SLP," also termed "specific absorption rate," is the rate of energy absorbed from the applied AMF per unit mass. A control sample of water showed no measurable heating.

Pharmacokinetics was measured after injection of the dose used for therapy (IV $1.7 \mathrm{~g} \mathrm{Fe} / \mathrm{kg}$ ). The concentration of iron in various tissues after subtraction of normal body iron is shown in Figure 2. For the measurement times assayed, the tumor concentration peaked at $1.9 \pm 0.3 \mathrm{mg} \mathrm{Fe} / \mathrm{cc}$ at 24 hours. The highest muscle concentration occurred at 8 hours, $0.12 \pm 0.02 \mathrm{mg} \mathrm{Fe} / \mathrm{cc}$, giving a peak tumor to peak non-tumor (surrounding muscle) ratio of 15.8. At 24 hours, the muscle content could not be distinguished from normal muscle iron content $\left(0.068 \mathrm{mg} \mathrm{Fe} / \mathrm{cc}^{66}\right)$, which would give a tumor to non-tumor ratio of $>16.0$ at 24 hours. Blood clearance exhibited a rapid early half-life of 2.0 hours followed by a slow component half-life of 14.0 hours.

An initial toxicity study determined the MTD50 (defined as the dose at which $50 \%$ of animals lost $>15 \%$ of original body weight any time within 1 month) to be $4.7 \mathrm{~g} \mathrm{Fe} / \mathrm{kg}$. Mice IV injected at $3.4 \mathrm{~g} \mathrm{Fe} / \mathrm{kg}$ have now survived $>12$ months without showing any clinical signs of toxicity.

Nude mice with subcutaneous squamous cell carcinomas (SCCVII) implanted in their legs were heated by placing the legs in an AMF (Figure 3). A stepping motor was used to scan the leg through the field so that it would be heated uniformly. A fiber-optic thermocouple was placed in the tumor center in test animals to determine the difference between the surface (measured with an infrared camera) and center of the tumor. This difference was less than $\pm 2^{\circ} \mathrm{C}$ (which has also been observed by others ${ }^{67}$ ), so the external temperature was used so as not to invasively disturb tissues. The tumor heating rate is shown in Figure 4. These experiments showed that tumors could be rapidly heated to ablative temperatures $\left(60^{\circ} \mathrm{C}\right.$ in 2 minutes) after a well-tolerated IV injection of MNPs. Due to the 16:1 MNP ratio of tumor to non-tumor surrounding tissue, normal tissue (with the same IV MNP injection and field) was found to have a temperature of $36^{\circ} \mathrm{C}$ after 2 minutes. Lowering the MNP injection by one-half $(0.85 \mathrm{~g} \mathrm{Fe} / \mathrm{kg})$ or lowering the field by one-half also resulted in ineffective treatment levels of a temperature $<42^{\circ} \mathrm{C}$ after 2 minutes. AMF alone without MNPs resulted in a leg temperature of $36^{\circ} \mathrm{C}$ after 2 minutes (Figure 4). We also noted that tumors after $2.6 \mathrm{~g} \mathrm{Fe} / \mathrm{kg} \mathrm{IV}$ administration were heated to $82^{\circ} \mathrm{C}$ in 2 minutes.

For therapy, mice with subcutaneous squamous cell carcinomas implanted on their legs were treated by IV injection of $1.7 \mathrm{~g} \mathrm{Fe} / \mathrm{kg}$ then their legs were heated 24 hours later using

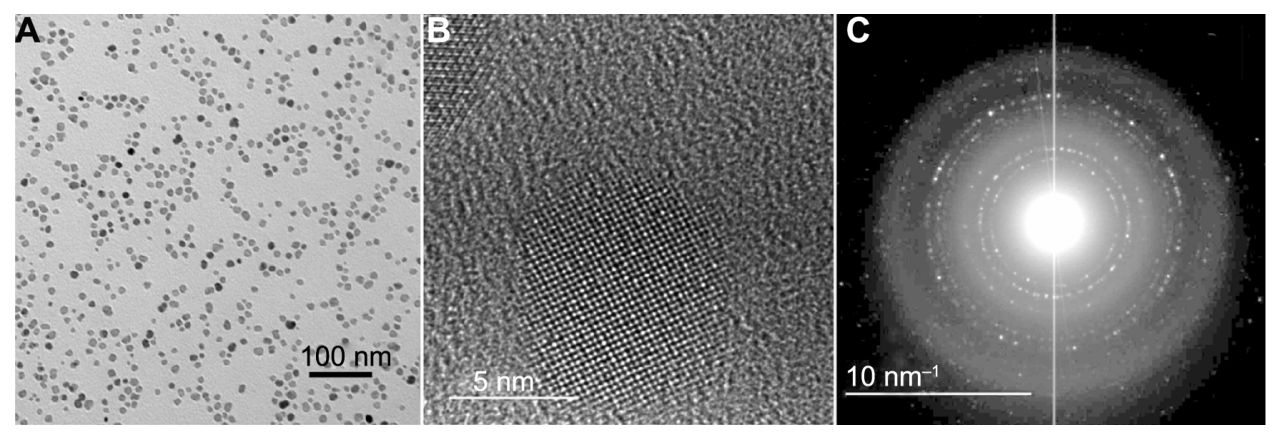

Figure I Transmission electron microscopy images of the magnetic nanoparticles. (A) Particle cores measured to be II.3 $\pm 2.3 \mathrm{~nm}(\mathrm{scale}$ bar $=\mathrm{I} 00 \mathrm{~nm})$. (B) High-resolution lattice image of a $9.9 \mathrm{~nm}$ particle showing its crystalline core $($ scale bar $=5 \mathrm{~nm})$. (C) Electron diffraction pattern, identifying cores as Fe $\mathrm{O}_{4}\left(\mathrm{scale}\right.$ bar $=10 \mathrm{~nm} \mathrm{~m}^{-1}$ ). 


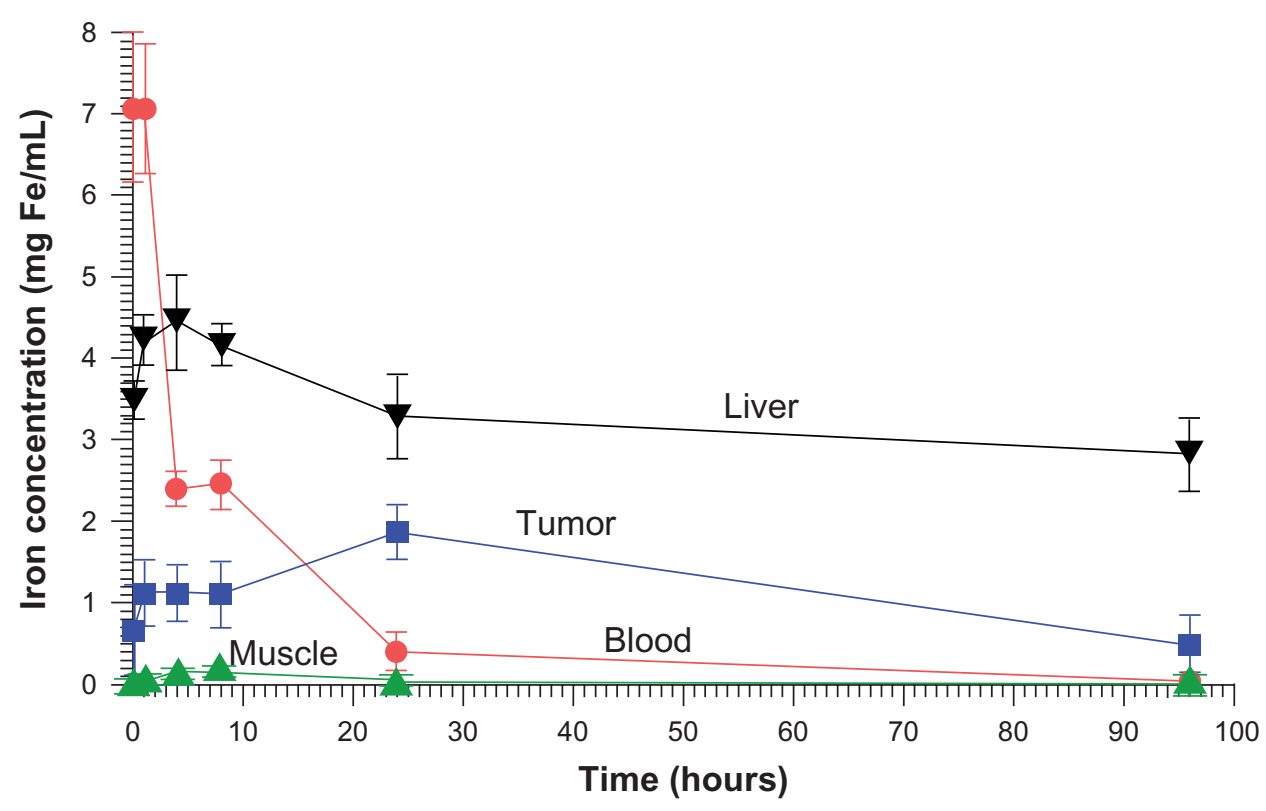

Figure 2 Biodistribution of iron (after subtraction of normal tissue iron) over time.

Notes: The maximum iron concentration in the tumor from the points measured was at 24 hours post-injection, reaching $1.9 \mathrm{mg}$ Fe/mL. Time points were: 5 minutes, I hour, and 4, 8, 24, and 96 hours.

the magnetic field. Results are shown in Figure 5. The amount of IV-administered MNPs delivered to the tumors was enough in combination with the field strength to effectively ablate nearly all tumors $(78 \%-90 \%$, results of two independent experiments). Control treatments (ie, no treatment, magnetic field treatment only, or MNP treatment only) had no measurable effect on tumor growth or survival. Successfully treated tumors were rapidly liquefied and resorbed in 1-2 days (Figure 6). After complete remission (at 160 days), mice had virtually the same leg diameter at the place of the tumor

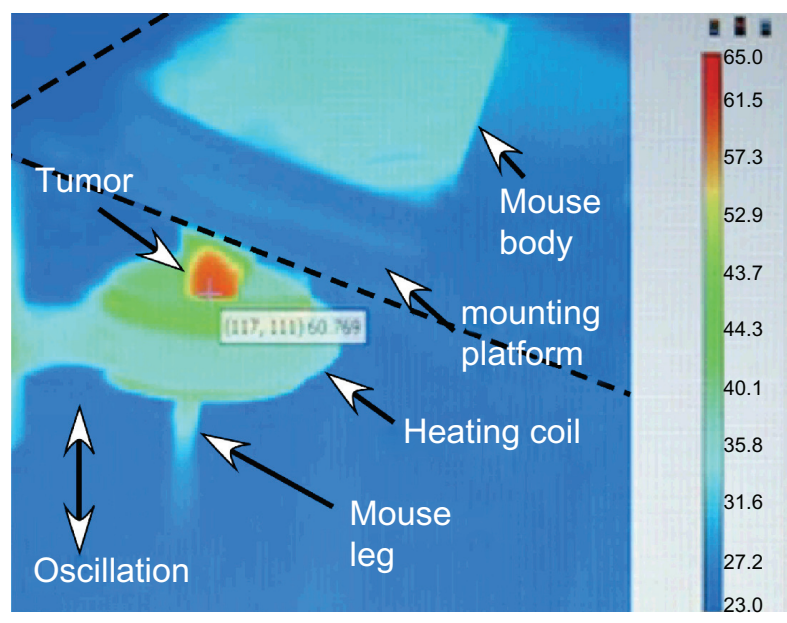

Figure 3 Thermal image of subcutaneous tumor being heated by an alternating magnetic field.

Notes: The leg was scanned up and down vertically to make the field uniform over the leg. The tumor can be observed to have specifically heated (red region).
(5.47 $\mathrm{mm}$ average) as at their untreated contralateral leg (5.53 $\mathrm{mm}$ average) with no leg dysfunction, indicating that the treatment was well confined with less than $\sim 1 \mathrm{~mm}$ of normal tissue damage.

\section{Discussion}

The extraordinary efficacy attained in our study for an extremely aggressive tumor ${ }^{68}$ can be attributed to a

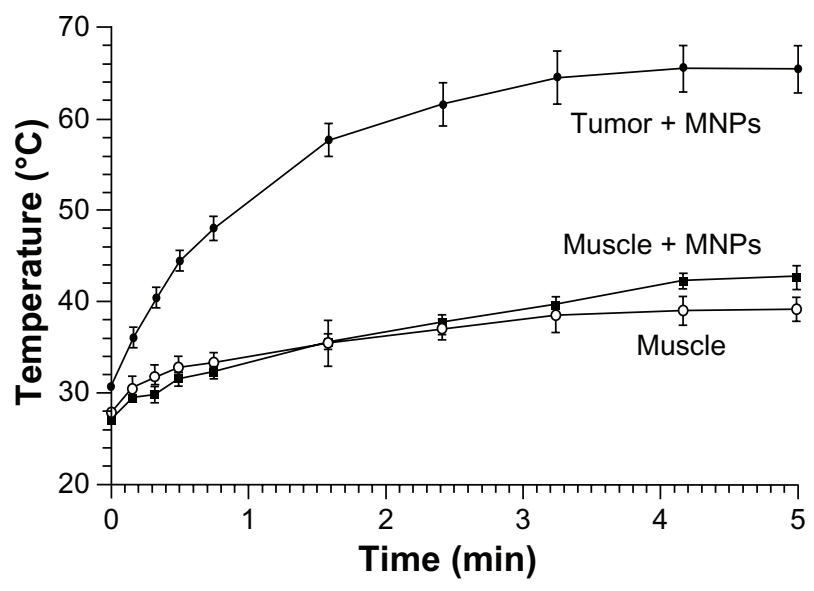

Figure 4 Heating of tissues in the magnetic field: 24 hours after an intravenous injection of magnetic nanoparticles (MNPs) $(1.7 \mathrm{~g} \mathrm{Fe} / \mathrm{kg}$ ) - tumor (filled circles) and leg muscle (no tumor, filled squares) tissues.

Notes: Also shown is heating of leg muscle tissue with no injection of MNPs (open circles). The alternating magnetic field applied was $38 \mathrm{kA} / \mathrm{m}$ at $980 \mathrm{kHz}$. Tumors (average size of $206 \mathrm{~mm}^{3}$, three averaged) equilibrated at $66^{\circ} \mathrm{C}$ after 5 minutes, muscle with MNPs reached $42^{\circ} \mathrm{C}$, and muscle without MNPs reached $39^{\circ} \mathrm{C}$. Three mice were used per group. 


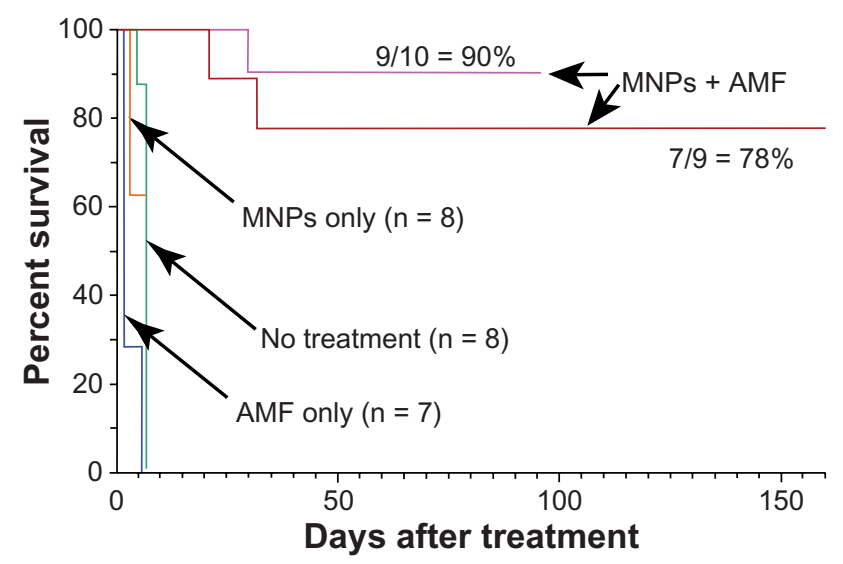

Figure 5 Magnetic nanoparticle (MNP) hyperthermia treatment. Notes: Intravenous injection of $1.7 \mathrm{~g} \mathrm{Fe} / \mathrm{kg}$ and followed 24 hours later by exposure to an alternating magnetic field $(38 \mathrm{kA} / \mathrm{m}, 980 \mathrm{kHz}, 2$ minutes) resulted in durable ablation of tumors $(7 / 9=78 \%, n=9$, absence of palpable tumor). A repeated experiment showed $90 \%(n=10)$ thermoablation. Controls - no treatment, magnetic field only, and only magnetic nanoparticles - had no measurable effect on survival. Abbreviations: AMF, alternating magnetic field; $n$, number of animals per group.

combination of six factors: (1) IV delivery that adequately loads carcinomas, (2) low systemic toxicity (MTD50 $4.8 \mathrm{~g}$ $\mathrm{Fe} / \mathrm{kg})$ that enabled sufficiently high tumor loading $(0.19 \%$ Fe) for effective heating, (3) good tumor to non-tumor ratio (>16:1), (4) MNPs that heated efficiently (SLP $754 \mathrm{~W} / \mathrm{g}$ ), (5) use of a high magnetic field ( $38 \mathrm{kA} / \mathrm{m}$ ), and (6) use of a high frequency $(980 \mathrm{kHz})$. Previous studies have indicated better heating with increased concentration, $\mathrm{SLP}^{60}$ field strength, and frequency ${ }^{69}$ thus stressing the importance of maximizing each parameter. The SLP also depends on the size and polydispersity of the MNPs, with larger and more uniform MNPs performing better. ${ }^{27}$ However, for the fields and size of MNPs used in this study, increased polydispersity may actually be

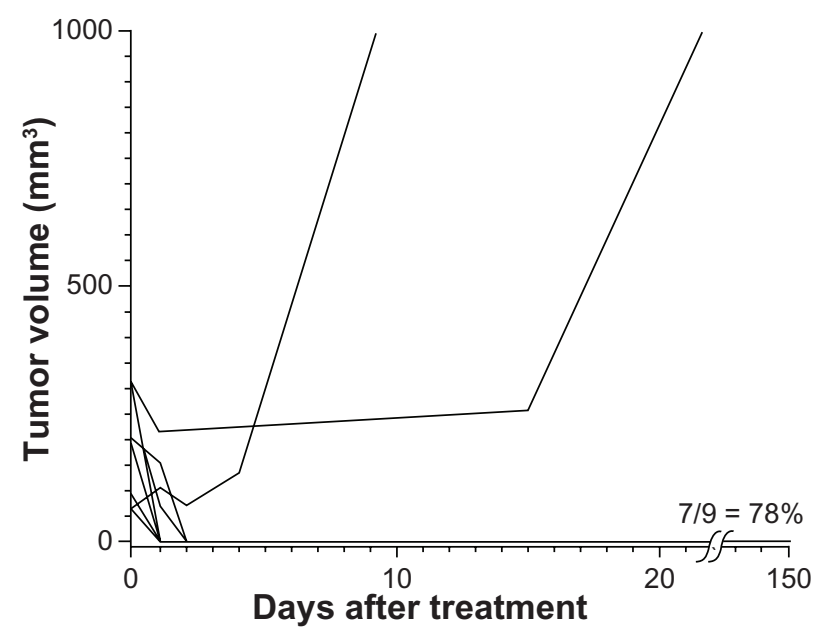

Figure 6 There was a rapid decrement in the volume of most tumors and debris was resorbed in I-2 days, completely deflating fairly large tumors. Note: The average tumor size at time of treatment was $196 \mathrm{~mm}^{3}$. preferable. ${ }^{1}$ The SLP of the particles used here $(754 \mathrm{~W} / \mathrm{g})$ compares favorably to conventional particles, $\sim 100-300 \mathrm{~W} / \mathrm{g}$ ( $9 \mathrm{~nm}$ size, $500 \mathrm{kHz}, 37.3 \mathrm{kA} / \mathrm{m}^{29}$ ) but is lower than constructs containing zinc, cobalt, and manganese, which reach $4000 \mathrm{~W} / \mathrm{g} .{ }^{29}$ However, other constructs may affect toxicity and delivery. PEG of MW 2000 is appropriate, since tumor uptake is not significantly different from higher MW PEG coatings and PEG of lower MW results in shorter blood half-life and higher macrophage uptake. ${ }^{70} \mathrm{PEG}$ of higher MW is more viscous and leads to potential problems with high-concentration injections. ${ }^{71}$ While there were a number of contributory factors to achieving durable remissions, the main advance in our study was the use of IV delivery. Although the resulting distribution of nanoparticles is not uniform throughout the tumor after IV administration, it leads to thorough tumor encasement, ${ }^{53,54}$ which can cut off blood supply (oxygen and nutrients) to central hypoxic regions, compared with direct injections that are punctate and can leave tumor regions untreated. ${ }^{41,52,72}$ Arterial administration of magnetic microparticles causing emboli in liver tumors followed by AMF heating was found to be vastly superior to direct injection of the same amount and AMF heating to the same temperature ${ }^{67} \mathrm{~A}$ heating strategy does not require perfect homogeneity, because the heat will either extend to adjacent cells that have fewer MNPs or starve entrapped regions. Ideally, the heating should cover the tumor's growing edge to be consistently effective, precisely where the leakage of IV nanoparticles is greatest. ${ }^{53,73-75} \mathrm{In}$ comparison with direct intratumoral injection, IV injection has the additional advantage of precisely loading many tumors simultaneously, which could then be treated in one application - a much needed strategy for metastases.

The present study focused on obtaining long-lasting cancer abatement in vivo to address the substantial obstacles encountered in transitioning from cell studies to animals with tumors. What appears exciting in vitro may easily fail in vivo. The translation from mice to humans is also fraught with uncertainty and new reasons for potential failure. Personnel at MagForce (Berlin, Germany) are to be commended for their construction of an appropriate AMF machine for humans and application to human prostate ${ }^{50}$ in 2005 and more recently to human gliomas. ${ }^{51,52,76}$ Direct intratumoral injection of MNPs into recurrent gliomas and AMF heating combined with radiotherapy resulted in a survival time (from primary diagnosis, "OS-1") of 23.2 months compared with 14.6 months (taken from another published study) with radiotherapy only. ${ }^{76,77}$ Another objective of the present study was to follow tumors for at least 3 months, since frequently a treatment that appears promising after 10-30 days has really 
only killed some of the tumor cells and tumors reappear after a month or more. ${ }^{78}$ In Tables 1 and 2, our results are compared with some other in vivo MNP treatments reported thus far. Table 1 shows studies using direct intratumoral injections of the MNPs and Table 2 shows those attempting intravenous administration. Our study (to 160 days) was the longest; many others report tumor response to only 14-35 days. For direct intratumoral injection (Table 1), several studies reported tumor-free survival. For example, Ito et $\mathrm{al}^{42}$ impressively controlled $1.5 \mathrm{~cm}$ tumors for at least 120 days by multiply retreating with intratumoral MNP injections and AMF heating treatments. It appears that direct intratumoral injections can be effective but are restricted by invasiveness and ability to produce adequate tumor MNP coverage. Fewer studies have been reported using IV injections (Table 2); those that have, all reported some tumor growth inhibition but all animals died of tumor overgrowth. Our study is the only one showing long term survival after IV administration. For other IV treatments, the maximum iron injected was $100 \mathrm{mg} \mathrm{Fe} / \mathrm{kg}$, presumably limited by toxicity. As has been noted previously, it is difficult to achieve the required tumor concentration by IV administration. ${ }^{79}$ In our study, $1.7 \mathrm{~g} \mathrm{Fe} / \mathrm{kg}$ was used and delivered a sufficient amount to the tumor. Another striking difference between our study and others is that only a single heat treatment of 2 minutes duration was used, while all other studies utilized a treatment time of at least 20 minutes and some performed multiple treatments.

The amount of iron used here is considerably larger than that used in other iron imaging or therapy applications. It was used for proof of principle to demonstrate that highly effective selective tumor heating can be obtained at a well-tolerated IV dose. The amount of iron might be reduced with further dosetime-temperature studies or use of particles with higher SLP. Nevertheless, this high amount of iron raises issues of toxicity and clearance. With a MTD50 of $4.8 \mathrm{~g} \mathrm{Fe} / \mathrm{kg}$, the magnetite particle used here (still investigational) is in the same range as US Food and Drug Administration-approved MNPs used as magnetic resonance imaging (MRI) contrast agents, which have been thoroughly tested for broad-spectrum toxicity, some of which have a median lethal dose (ie, lethal dose, $50 \%$ [LD50]) of $6 \mathrm{~g} / \mathrm{kg} .{ }^{63}$ At $1.7 \mathrm{~g} \mathrm{Fe} / \mathrm{kg}$, the amount of iron given to a human would be $\sim 119 \mathrm{~g}$ Fe, 34 times the normal body iron content of $3.5 \mathrm{~g}$. At this level in mice we observed no obvious clinical signs of toxicity (no weight loss or abnormal behavior) over the course of 1 year, but there was darkening of the skin that very gradually cleared over several months. The stability and slow breakdown of the particles is key to their not imposing any sudden toxic free iron load. This might be considered similar to swallowing arsenic encased in a glass bead, which would produce no adverse effects. Thus, the surprisingly large amount of iron should not be grounds for immediate dismissal of consideration for human use. Rejection should also not be based on comparison with other iron compounds, since each compound or construct has its own, often radically different, toxicity profile. In addition, if the method eradicates cancers when other methods do not, minor side effects could be tolerated. For example, cisplatin has a LD50 of $11 \mathrm{mg} / \mathrm{kg}$ IV in mice. ${ }^{80}$ Scaled by body surface area, it would have a projected human equivalent LD50 of $0.89 \mathrm{mg} / \mathrm{kg} .{ }^{81}$ However, standard human treatment doses are $2.5 \mathrm{mg} / \mathrm{kg}\left(100 \mathrm{mg} / \mathrm{m}^{2}\right),{ }^{82} 2.8$ times higher than the LD50 predicted from animal studies. In any case, more thorough toxicity studies are needed.

Liver uptake per gram for the MNPs is greater than for the tumor (Figure 2). This is commonly the case for intravenously injected materials. It might imply that tumors near the liver should be avoided by the locally applied magnetic field, but not necessarily, since the liver regenerates and often half or more is resected surgically to remove tumors. ${ }^{83}$ Liver tumors might be treated if sufficient differential tumor delivery could be achieved by targeting or hepatic artery administration. ${ }^{67}$

Tumor targeting in this study was by the enhanced permeability and retention effect. ${ }^{84,85}$ Targeting by antibodies, peptides, porphyrins, drugs, or other tumor-binding molecules or, alternatively, targeting tumor vasculature, tumor-related, and tumor environment ${ }^{86}$ epitopes could improve tumor uptake and specificity and lower the amount needed for injection. A potential problem with previously trialed MNPs coated with dextran was their rapid removal by liver and spleen. At 1 hour post-injection, dextran MNPs had 52\% of the injected dose in the liver and spleen, ${ }^{30}$ compared with $16 \%$ for the MNPs used here. Another study used $20 \mathrm{~nm}$ antibodytargeted intravenously administered MNPs, which produced a tumor uptake of $14 \%$ injected dose per gram of tissue $(\mathrm{id} / \mathrm{g}),{ }^{58}$ higher than our $6 \% \mathrm{id} / \mathrm{g}$, but the injected amount was $\sim 1.6 \mathrm{mg}$ compared with our $\sim 42 \mathrm{mg}$, resulting in tumor concentrations of $\sim 0.2 \mathrm{mg} \mathrm{Fe} / \mathrm{g}$ versus our $1.9 \mathrm{mg} \mathrm{Fe} / \mathrm{g}$. Their study showed delay of tumor doubling time but no complete remissions, consistent with basic studies indicating the need for higher concentrations in the tumor. ${ }^{60,61}$

External magnetic focusing (such as placement of external magnets or fields) to guide MNPs to an internal location is not stably possible, since external fields are strongest at their origin and MNPs move in a field gradient toward such an external source; that is, the MNPs would move toward the skin. Therefore, biotargeting appears to be the most fruitful approach to localizing MNPs to internal 


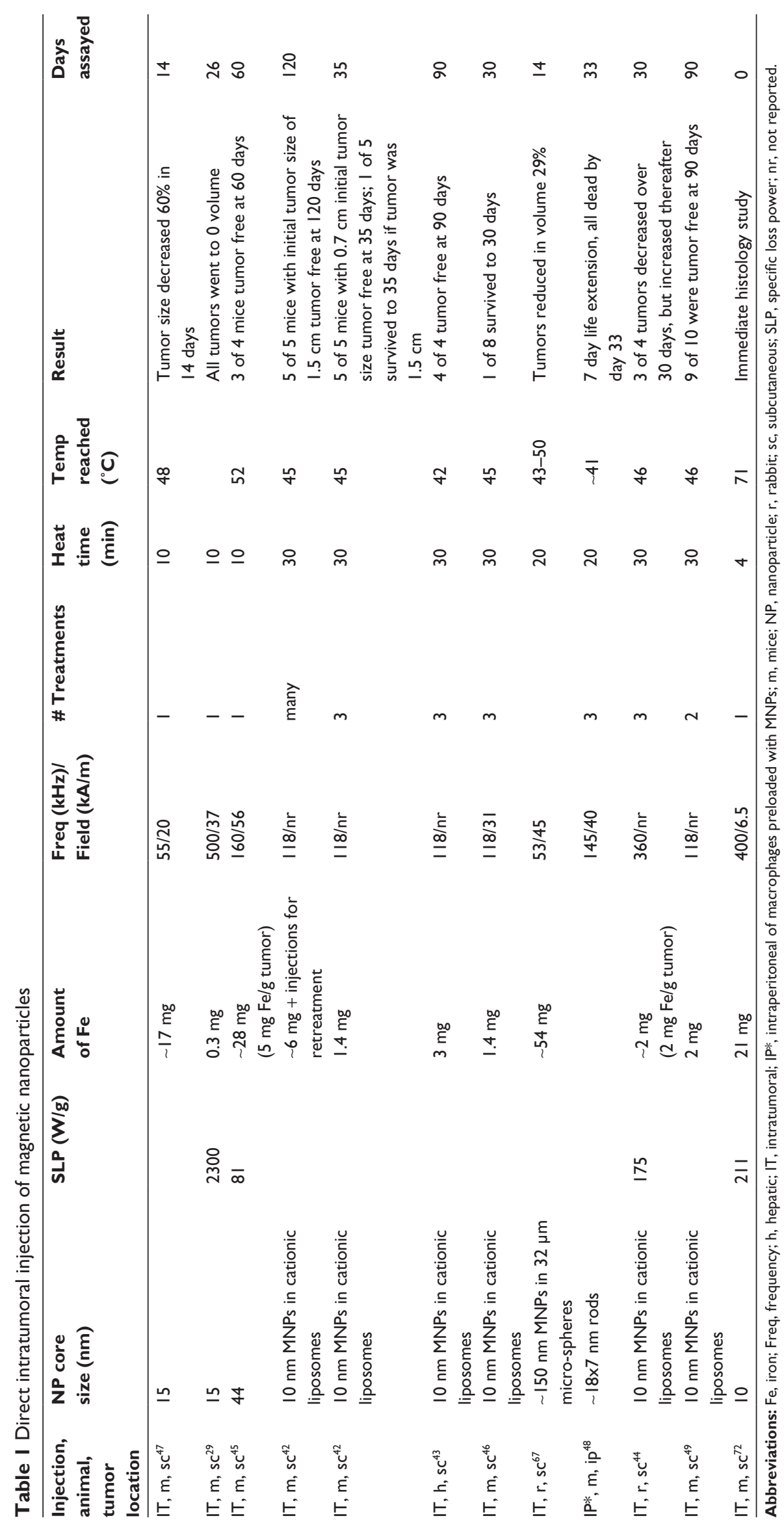


Table 2 Intravenous injection of magnetic nanoparticles

\begin{tabular}{|c|c|c|c|c|c|c|c|c|c|}
\hline $\begin{array}{l}\text { Injection, } \\
\text { animal, } \\
\text { tumor } \\
\text { location }\end{array}$ & $\begin{array}{l}\text { NP core } \\
\text { size }(\mathrm{nm})\end{array}$ & $\begin{array}{l}\text { SLP } \\
(W / g)\end{array}$ & $\begin{array}{l}\text { Amount } \\
\text { of Fe }\end{array}$ & $\begin{array}{l}\text { Freq } \\
(\mathrm{kHz}) / \\
\text { Field } \\
(\mathrm{kA} / \mathrm{m})\end{array}$ & $\begin{array}{l}\# \\
\text { Treatments }\end{array}$ & $\begin{array}{l}\text { Heat } \\
\text { time } \\
(\mathrm{min})\end{array}$ & $\begin{array}{l}\text { Temp } \\
\text { reached } \\
\left({ }^{\circ} \mathrm{C}\right)\end{array}$ & Result & $\begin{array}{l}\text { Days } \\
\text { assayed }\end{array}$ \\
\hline $\mathrm{IV}, \mathrm{m}, \mathrm{sc}^{58}$ & 20 & $\sim 75$ & $\sim 100 \mathrm{mg} / \mathrm{kg}$ & $153 / 56$ & 1 & 20 & & $\begin{array}{l}\text { Doubling time } 20 \text { days } \\
\text { compared to control } \\
\text { I I days, no survivors }\end{array}$ & 50 \\
\hline $\mathrm{IV}, \mathrm{m}, \mathrm{sc}^{59}$ & $\begin{array}{l}10 \mathrm{~nm} \\
\text { MNPs in antibody- } \\
\text { liposomes }\end{array}$ & 96 & $\sim 100 \mathrm{mg} / \mathrm{kg}$ & || $8 / 3 \mid$ & 3 & 30 & 43 & $\begin{array}{l}\text { Survival better than } \\
\text { untreated but all animals } \\
\text { dead by day } 75\end{array}$ & 75 \\
\hline IA, $r, h^{67}$ & $\begin{array}{l}\sim 150 \mathrm{~nm} \text { MNPs in } \\
32 \text { um micro- } \\
\text { spheres }\end{array}$ & & $\sim 54 \mathrm{mg}$ & $53 / 45$ & I & 20 & $43-50$ & $\begin{array}{l}\text { Tumors reduced in volume } \\
79 \% \text {; found superior to } \\
\text { direct injection }\end{array}$ & \\
\hline $\begin{array}{l}\text { IV, m, sc } \\
\text { (this study) }\end{array}$ & 11 & 754 & $1.7 \mathrm{~g} / \mathrm{kg}$ & $980 / 38$ & 1 & 2 & 60 & $\begin{array}{l}7 \text { of } 9(78 \%) \text { tumor free at } \\
160 \text { days }\end{array}$ & 160 \\
\hline
\end{tabular}

Abbreviations: Fe, iron; Freq, frequency; h, hepatic; IV, intravenous; IA, intraarterial; m, mice; MNP, magnetic nanoparticle; NP, nanoparticle; $r$, rabbit; sc, subcutaneous; SLP, specific loss power.

tumors. However, to some extent, the field can be shaped with external low-reluctance material to help avoid critical regions. ${ }^{87}$

It appears that the method presented here is powerful enough to heat and ablate tumors (at least in mice), but it must be applied judiciously, as overheating can damage surrounding normal tissue due to direct heat conduction and blood-flow heat transfer. Many proteins denature at $\sim 55^{\circ} \mathrm{C}$. Controls indicated that the amount of MNPs in normal tissue did not significantly contribute to normal tissue heating, since with or without MNPs, both showed the same $36^{\circ} \mathrm{C}$ temperature after 2 minutes (Figure 4). Optimization of a heating protocol is critical to minimizing normal surrounding tissue damage. Here, we chose to heat tumors rapidly to ablative temperatures for a short total time ( $\sim 2$ minutes), as opposed to heating slowly, which would allow adjacent normal tissue to equilibrate with the tumor temperature. This strategy protected the underlying leg from damage. However, other protocols might be to heat for a longer time at lower temperatures, which would lead to cellular apoptosis rather than necrosis. Theoretical thermodynamic studies have been reported that address the optimal application of magnetic hyperthermia. ${ }^{88,89}$ For clinical use, it may be envisioned that dose planning will be undertaken similarly to that for radiation. The iron concentrations can be mapped by MRI, computed tomography, or magnetorelaxometry ${ }^{51,90,91}$ and, knowing the precise SLP of the particles and field strength, the heating topography can be predicted, as has been done in human magnetic nanoparticle brain tumor hyperthermia treatments. ${ }^{76}$ Subjection to a tissue/ blood-flow modeling program can approximate the heating profile without the need for multiple invasive thermocouples. It would be difficult to measure internal temperatures in real-time by MRI, since the induction heating equipment would have to be non-magnetic.

For clinical application, there is also concern about eddy current heating in normal tissues at high fields and frequencies. ${ }^{10,41}$ However, this might be countered by increasing the SLP of the particles, reducing the frequency, application to smaller diameters such as head or extremities, and lower target temperatures. Hyperthermia has long been known to be synergistic with chemotherapy and radiotherapy ${ }^{78,92-94}$ and requires much lower temperatures $\left(\sim 40^{\circ} \mathrm{C}-43^{\circ} \mathrm{C}\right)$.

\section{Conclusion}

The IV delivery of biocompatible magnetic nanoparticles is now able to achieve the tumor iron concentrations needed for effective hyperthermia. With these concentrations and a high tumor to non-tumor ratio, precise tumor ablation is now possible. Because IV delivery generally loads tumors better than direct intratumoral injection, conforming to tumors' irregular shapes, this advance in mice may be of use clinically. Combination with chemotherapy or radiotherapy should enhance their efficacy.

\section{Acknowledgments}

The authors thank Ms Natalie Muratori, Dr Yimei Zhu, Ms Lynn Lin, Thomas Zimmerman, DVM, Dr Henry M Smilowitz, Daniel N Slatkin, MD, Cat Hainfeld, and the Nanotechnology Characterization Laboratory of the National Institutes of Health for assistance.

\section{Disclosure}

$\mathrm{J}$ Hainfeld is a part owner of Nanoprobes. H Huang has no conflicts of interest to declare in relation to this work. 


\section{References}

1. Hergt R, Dutz S, Röder M. Effects of size distribution on hysteresis losses of magnetic nanoparticles for hyperthermia. J Phys Condens Matter. 2008;20(38):385214.

2. Rosensweig RE. Heating magnetic fluid with alternating magnetic field. J Magn Magn Mater. 2002;252(1-3):370-374.

3. Gilchrist RK, Medal R, Shorey WD, Hanselman RC, Parrott JC, Taylor CB. Selective inductive heating of lymph nodes. Annals of surgery. 1957;146(4):596-606.

4. Chan DC, Kirpotin DB, Bunn PA Jr. Synthesis and evaluation of colloidal magnetic iron oxides for the site-specific radiofrequency-induced hyperthermia of cancer. J Magn Magn Mater. 1993;122(1-3):374-378.

5. Jordan A, Wust P, Fahling H, John W, Hinz A, Felix R. Inductive heating of ferrimagnetic particles and magnetic fluids: physical evaluation of their potential for hyperthermia. Int J Hyperthermia. 1993;9(1):51-68.

6. Rand RW, Snow HD, Brown WJ. Thermomagnetic surgery for renal cancer. Prog Clin Biol Res. 1982;100:673-685.

7. Kumar CS, Mohammad F. Magnetic nanomaterials for hyperthermiabased therapy and controlled drug delivery. Adv Drug Deliv Rev. 2011;63(9):789-808.

8. Laurent S, Dutz S, Häfeli UO, Mahmoudi M. Magnetic fluid hyperthermia: focus on superparamagnetic iron oxide nanoparticles. $A d v$ Colloid Interface Sci. 2011;166(1-2):8-23.

9. Berry CC. Progress in functionalization of magnetic nanoparticles for applications in biomedicine. J Phys D Appl Phys. 2009;42(22).

10. Pankhurst QA, Thanh NT, Jones SK, Dobson J. Progress in applications of magnetic nanoparticles in biomedicine. J Phys D Appl Phys. 2009;42(22).

11. Roca AG, Costo R, Rebolledo AF, et al. Progress in the preparation of magnetic nanoparticles for applications in biomedicine. J Phys D Appl Phys. 2009;42(22).

12. Kobayashi T. Cancer hyperthermia using magnetic nanoparticles. Biotechnology journal. 2011;6(11):1342-1347.

13. Amstad E, Reimhult E. Nanoparticle actuated hollow drug delivery vehicles. Nanomedicine (Lond). 2012;7(1):145-164.

14. Edelman ER, Brown L, Kost J, Taylor J, Langer R. Modulated release from polymeric drug delivery systems using oscillating magnetic fields: in vitro and in vivo characteristics. Transactions - American Society for Artificial Internal Organs. 1984;30:445-449.

15. Kost J, Noecker R, Kunica E, Langer R. Magnetically controlled release systems: effect of polymer composition. Journal of biomedical materials research. 1985;19(8):935-940.

16. Kost J, Wolfrum J, Langer R. Magnetically enhanced insulin release in diabetic rats. Journal of biomedical materials research. 1987;21(12):1367-1373.

17. Su W, Wang H, Wang S, et al. PEG/RGD-modified magnetic polymeric liposomes for controlled drug release and tumor cell targeting. International journal of pharmaceutics. 15 2012;426(1-2):170-181.

18. Hosokawa T, Sami M, Kato Y, Hayakawa E. Alteration in the temperaturedependent content release property of thermosensitive liposomes in plasma. Chemical \& pharmaceutical bulletin. 2003;51(11):1227-1232.

19. Masuko Y, Tazawa K, Viroonchatapan E, et al. Possibility of thermosensitive magnetoliposomes as a new agent for electromagnetic induced hyperthermia. Biol Pharm Bull. 1995;18(12):1802-1804.

20. Viroonchatapan E, Sato H, Ueno M, et al. Microdialysis assessment of 5-fluorouracil release from thermosensitive magnetoliposomes induced by an electromagnetic field in tumor-bearing mice. $J$ Drug Target. 1998;5(5):379-390.

21. Peiris PM, Bauer L, Toy R, et al. Enhanced delivery of chemotherapy to tumors using a multicomponent nanochain with radio-frequency-tunable drug release. ACS nano. 2012;6(5):4157-4168.

22. Babincov M, Altanerov V, Altaner C, Bergemann C, Babinec P. In vitro analysis of cisplatin functionalized magnetic nanoparticles in combined cancer chemotherapy and electromagnetic hyperthermia. IEEE Trans Nanobioscience. 2008;7(1):15-19.
23. Zhang J, Misra RD. Magnetic drug-targeting carrier encapsulated with thermosensitive smart polymer: core-shell nanoparticle carrier and drug release response. Acta Biomater. 2007;3(6):838-850.

24. Hu SH, Liao BJ, Chiang CS, Chen PJ, Chen IW, Chen SY. Core-shell nanocapsules stabilized by single-component polymer and nanoparticles for magneto-chemotherapy/hyperthermia with multiple drugs. $A d v$ Mater. 2012;24(27):3627-3632.

25. Ren Y, Zhang H, Chen B, et al. Multifunctional magnetic Fe3O4 nanoparticles combined with chemotherapy and hyperthermia to overcome multidrug resistance. International Journal of Nanomedicine. 2012;7:2261-2269.

26. Le Renard PE, Jordan O, Faes A, et al. The in vivo performance of magnetic particle-loaded injectable, in situ gelling, carriers for the delivery of local hyperthermia. Biomaterials. 2010;31(4):691-705.

27. Park J, An K, Hwang Y, et al. Ultra-large-scale syntheses of monodisperse nanocrystals. Nat Mater. 2004;3(12):891-895.

28. Fortin JP, Wilhelm C, Servais J, Ménager C, Bacri JC, Gazeau F. Size-sorted anionic iron oxide nanomagnets as colloidal mediators for magnetic hyperthermia. J Am Chem Soc. 2007;129(9):2628-2635.

29. Lee JH, Jang JT, Choi JS, et al. Exchange-coupled magnetic nanoparticles for efficient heat induction. Nat Nanotechnol. 2011;6(7):418-422.

30. Lacava LM, Lacava ZGM, Azevedo RB, et al. Use of magnetic resonance to study biodistribution of dextran-coated magnetic fluid intravenously administered in mice. J Magn Magn Mater. 2002; 252(1-3).

31. White DL, Aicher KP, Tzika AA, Kucharczyk J, Engelstad BL, Moseley ME. Iron-dextran as a magnetic susceptibility contrast agent: flow-related contrast effects in the T2-weighted spin-echo MRI of normal rat and cat brain. Magn Reson Med. 1992;24(1):14-28.

32. Kohler N, Sun C, Fichtenholtz A, Gunn J, Fang C, Zhang M. Methotrexate-immobilized poly(ethylene glycol) magnetic nanoparticles for MR imaging and drug delivery. Small. 2006;2(6):785-792.

33. Xie J, Xu C, Xu Z, et al. Linking Hydrophilic Macromolecules to Monodisperse Magnetite ( $\mathrm{Fe}(3) \mathrm{O}(4))$ Nanoparticles via Trichloro-striazine. Chem Mater. 2006;18(23):5401-5403.

34. Jordan A, Scholz R, Wust P, et al. Endocytosis of dextran and silancoated magnetite nanoparticles and the effect of intracellular hyperthermia on human mammary carcinoma cells in vitro. J Magn Magn Mater. 1999;194(1-3):185-196.

35. Carpenter EE. Iron nanoparticles as potential magnetic carriers. J Magn Magn Mater. 2001;225(1-2):17-20.

36. Park HY, Schadt MJ, Wang L, et al. Fabrication of magnetic core@ shell Fe oxide@Au nanoparticles for interfacial bioactivity and bioseparation. Langmuir. 2007;23(17):9050-9056.

37. Miller KJ, Colletti A, Papi PJ, McHenry ME. Fe-Co-Cr nanocomposites for application in self-regulated rf heating. J Appl Phys. 2010; 107(9).

38. Shido Y, Nishida Y, Suzuki Y, Kobayashi T, Ishiguro N. Targeted hyperthermia using magnetite cationic liposomes and an alternating magnetic field in a mouse osteosarcoma model. J Bone Joint Surg Br 2010;92(4):580-585.

39. Pop M, Cosma-Cachita D, Bica D, Tarca A, Tripşa M. Magnetoliposomes obtained from lecithin and Fe3O4 nanoparticles. Rom J Physiol. 1999;36(3-4):233-236.

40. Skouras A, Mourtas S, Markoutsa E, et al. Magnetoliposomes with high USPIO entrapping efficiency, stability and magnetic properties. Nanomedicine. 2011;7(5):572-579.

41. Hilger I, Hergt R, Kaiser WA. Use of magnetic nanoparticle heating in the treatment of breast cancer. IEE Proc Nanobiotechnol. 2005;152(1): 33-39.

42. Ito A, Tanaka K, Honda H, Abe S, Yamaguchi H, Kobayashi T. Complete regression of mouse mammary carcinoma with a size greater than $15 \mathrm{~mm}$ by frequent repeated hyperthermia using magnetite nanoparticles. J Biosci Bioeng. 2003;96(4):364-369.

43. Matsuoka F, Shinkai M, Honda H, Kubo T, Sugita T, Kobayashi T. Hyperthermia using magnetite cationic liposomes for hamster osteosarcoma. Biomagn Res Technol. 2004;2(1):3. 
44. Motoyama J, Yamashita N, Morino T, Tanaka M, Kobayashi T, Honda H. Hyperthermic treatment of DMBA-induced rat mammary cancer using magnetic nanoparticles. Biomagn Res Technol. 2008;6:2.

45. Dennis CL, Jackson AJ, Borchers JA, et al. Nearly complete regression of tumors via collective behavior of magnetic nanoparticles in hyperthermia. Nanotechnology. 2009;20(39):395103.

46. Tanaka K, Ito A, Kobayashi T, et al. Heat immunotherapy using magnetic nanoparticles and dendritic cells for T-lymphoma. J Biosci Bioeng 2005;100(1):112-115.

47. Zhai Y, Xie H, Gu H. Effects of hyperthermia with dextran magnetic fluid on the growth of grafted $\mathrm{H} 22$ tumor in mice. Int J Hyperthermia. 2009;25(1):65-71.

48. Basel MT, Balivada S, Wang H, et al. Cell-delivered magnetic nanoparticles caused hyperthermia-mediated increased survival in a murine pancreatic cancer model. International journal of nanomedicine. 2012; 7:297-306

49. Suzuki M, Shinkai M, Honda H, Kobayashi T. Anticancer effect and immune induction by hyperthermia of malignant melanoma using magnetite cationic liposomes. Melanoma research. 2003;13(2):129-135.

50. Johannsen M, Gneveckow U, Eckelt L, et al. Clinical hyperthermia of prostate cancer using magnetic nanoparticles: presentation of a new interstitial technique. Int J Hyperthermia. 2005;21(7):637-647.

51. Maier-Hauff K, Rothe R, Scholz R, et al. Intracranial thermotherapy using magnetic nanoparticles combined with external beam radiotherapy: results of a feasibility study on patients with glioblastoma multiforme. J Neurooncol. 2007;81(1):53-60.

52. van Landeghem FK, Maier-Hauff K, Jordan A, et al. Post-mortem studies in glioblastoma patients treated with thermotherapy using magnetic nanoparticles. Biomaterials. 2009;30(1):52-57.

53. Hainfeld JF, O'Connor MJ, Dilmanian FA, Slatkin DN, Adams DJ, Smilowitz HM. Micro-CT enables microlocalisation and quantification of Her2-targeted gold nanoparticles within tumour regions. Br J Radiol. 2011;84(1002):526-533.

54. Hainfeld JF, Smilowitz HM, O'Connor MJ, Dilmanian FA, Slatkin DN Gold nanoparticle imaging and radiotherapy of brain tumors in mice. Nanomedicine (Lond). Epub December 24, 2012.

55. Dutz S, Kettering M, Hilger I, Muller R, Zeisberger M. Magnetic particle hyperthermia - Properties of magnetic multicore nanoparticles administered to tumor tissue. Biomedizinische Technik. Biomedical engineering. 2012:76.

56. Hilger I, Hiergeist R, Hergt R, Winnefeld K, Schubert H, Kaiser WA. Thermal ablation of tumors using magnetic nanoparticles: an in vivo feasibility study. Invest Radiol. 2002;37(10):580-586.

57. Balivada S, Rachakatla RS, Wang H, et al. A/C magnetic hyperthermia of melanoma mediated by iron(0)/iron oxide core/shell magnetic nanoparticles: a mouse study. BMC Cancer. 2010;10:119.

58. DeNardo SJ, DeNardo GL, Natarajan A, et al. Thermal dosimetry predictive of efficacy of $111 \mathrm{In}$-ChL6 nanoparticle AMF - induced thermoablative therapy for human breast cancer in mice. $J$ Nucl Med. 2007;48(3):437-444.

59. Shinkai M, Le B, Honda H, et al. Targeting hyperthermia for renal cell carcinoma using human MN antigen-specific magnetoliposomes. Jpn J Cancer Res. 2001;92(10):1138-1145.

60. Hergt R, Dutz S. Magnetic particle hyperthermia - biophysical limitations of a visionary tumour therapy. JMagn Magn Mater. 2007;311(1): 187-192.

61. Samanta B, Yan H, Fischer NO, Shi J, Jerry DJ, Rotello VM. Proteinpassivated $\mathrm{Fe}(3) \mathrm{O}(4)$ nanoparticles: low toxicity and rapid heating for thermal therapy. J Mater Chem. 2008;18(11):1204-1208.

62. Lévy M, Wilhelm C, Siaugue JM, Horner O, Bacri JC, Gazeau F. Magnetically induced hyperthermia: size-dependent heating power of $\gamma-\mathrm{Fe}_{2} \mathrm{O}_{3}$ nanoparticles. J Phys Condens Matter. 2008;20(20):204133.

63. Mornet S, Vasseur S, Grasset F, Duguet E. Magnetic nanoparticle design for medical diagnosis and therapy. J Mater Chem. 2004;14(14): 2161-2175.

64. Ceriotti F, Ceriotti G. Improved direct specific determination of serum iron and total iron-binding capacity. Clin Chem. 1980;26(2):327-331.
65. Yang T, Shen C, Li Z, et al. Highly ordered self-assembly with large area of Fe3O4 nanoparticles and the magnetic properties. J Phys Chem B. 2005;109(49):23233-23236.

66. Reardon TF, Allen DG. Iron injections in mice increase skeletal muscle iron content, induce oxidative stress and reduce exercise performance. Exp Physiol. 2009;94(6):720-730.

67. Moroz P, Jones SK, Gray BN. Tumor response to arterial embolization hyperthermia and direct injection hyperthermia in a rabbit liver tumor model. J Surg Oncol. 2002;80(3):149-156.

68. Nomura T, Shibahara T, Katakura A, Matsubara S, Takano N. Establishment of a murine model of bone invasion by oral squamous cell carcinoma. Oral Oncol. 2007;43(3):257-262.

69. Glöckl G, Hergt R, Zeisberger M, Dutz S, Nagel S, Weitschies W. The effect of field parameters, nanoparticle properties and immobilization on the specific heating power in magnetic particle hyperthermia. J Phys Condens Matter. 2006;18(38):S2935.

70. Larsen EK, Nielsen T, Wittenborn T, et al. Accumulation of magnetic iron oxide nanoparticles coated with variably sized polyethylene glycol in murine tumors. Nanoscale. 2012;4(7):2352-2361.

71. Chen B, Zuberi M, Borgens RB, Cho Y. Affinity for, and localization of, PEG-functionalized silica nanoparticles to sites of damage in an ex vivo spinal cord injury model. Journal of biological engineering. 2012;6(1):18.

72. Hilger I, Andrä W, Hergt R, Hiergeist R, Schubert H, Kaiser WA Electromagnetic heating of breast tumors in interventional radiology: in vitro and in vivo studies in human cadavers and mice. Radiology. 2001;218(2):570-575.

73. Seymour LW. Passive tumor targeting of soluble macromolecules and drug conjugates. Crit Rev Ther Drug Carrier Syst. 1992;9(2):135-187.

74. Maeda H, Nakamura H, Fang J. The EPR effect for macromolecular drug delivery to solid tumors: improvement of tumor uptake, lowering of systemic toxicity, and distinct tumor imaging in vivo. Adv Drug Deliv Rev. 2013;65(1):71-79.

75. Danquah MK, Zhang XA, Mahato RI. Extravasation of polymeric nanomedicines across tumor vasculature. Adv Drug Deliv Rev. 2011;63(8) 623-639.

76. Maier-Hauff K, Ulrich F, Nestler D, et al. Efficacy and safety of intratumoral thermotherapy using magnetic iron-oxide nanoparticles combined with external beam radiotherapy on patients with recurrent glioblastoma multiforme. J Neurooncol. 2011;103(2):317-324.

77. Stupp R, Mason WP, van den Bent MJ, et al. Radiotherapy plus concomitant and adjuvant temozolomide for glioblastoma. The New England journal of medicine. 2005;352(10):987-996.

78. Hainfeld JF, Dilmanian FA, Zhong Z, Slatkin DN, Kalef-Ezra JA, Smilowitz HM. Gold nanoparticles enhance the radiation therapy of a murine squamous cell carcinoma. Phys Med Biol. 2010;55(11): 3045-3059.

79. Dutz S, Kettering M, Hilger I, Müller R, Zeisberger M. Magnetic multicore nanoparticles for hyperthermia - influence of particle immobilization in tumour tissue on magnetic properties. Nanotechnology. 2011;22(26):265102.

80. Lewis R. Sax's Dangerous Properties of Industrial Materials. Vol 1-3. 9 ed. New York: Van Nostrand Reinhold; 1996:2722.

81. Reagan-Shaw S, Nihal M, Ahmad N. Dose translation from animal to human studies revisited. FASEB J. 2008;22(3):659-661.

82. Pfizer. Cisplatin injection [product information]. New York, NY: Pfizer; nd [updated Apr 2012]. Available from: http://www.pfizer.com/files/ products/uspi_cisplatin.pdf. Accessed January 5, 2013.

83. Adson MA, van Heerden JA, Adson MH, Wagner JS, Ilstrup DM. Resection of hepatic metastases from colorectal cancer. Arch Surg. 1984;119(6):647-651.

84. Noguchi Y, Wu J, Duncan R, et al. Early phase tumor accumulation of macromolecules: a great difference in clearance rate between tumor and normal tissues. Jpn J Cancer Res. 1998;89(3):307-314.

85. Dvorak HF, Nagy JA, Dvorak JT, Dvorak AM. Identification and characterization of the blood vessels of solid tumors that are leaky to circulating macromolecules. Am J Pathol. 1988;133(1):95-109. 
86. Yao L, Danniels J, Moshnikova A, et al. pHLIP peptide targets nanogold particles to tumors. Proc Natl Acad Sci U S A. 2013;110(2):465-470.

87. Ivkov R, DeNardo SJ, Daum W, et al. Application of high amplitude alternating magnetic fields for heat induction of nanoparticles localized in cancer. Clin Cancer Res. 2005;11(19 Pt 2):7093s-7103s.

88. Liangruksa M, Ganguly R, Puri IK. Parametric investigation of heating due to magnetic fluid hyperthermia in a tumor with blood perfusion. J Magn Magn Mater. 2011;323(6):708-716.

89. Hergt R, Andra W, d'Ambly CG, et al. Physical limits of hyperthermia using magnetite fine particles. IEEE Trans Magn. 1998;34(5): 3745-3754.

90. Wiekhorst F, Steinhoff U, Eberbeck D, Trahms L. Magnetorelaxometry assisting biomedical applications of magnetic nanoparticles. Pharm Res. 2012;29(5):1189-1202.
91. Yuan Y, Wyatt C, Maccarini P, et al. A heterogeneous human tissue mimicking phantom for RF heating and MRI thermal monitoring verification. Phys Med Biol. 2012;57(7):2021-2037.

92. Hildebrandt B, Wust P, Ahlers O, et al. The cellular and molecular basis of hyperthermia. Crit Rev Oncol Hematol. 2002;43(1):33-56.

93. Rao W, Deng ZS, Liu J. A review of hyperthermia combined with radiotherapy/chemotherapy on malignant tumors. Crit Rev Biomed Eng. 2010;38(1):101-116.

94. Wust P, Hildebrandt B, Sreenivasa G, et al. Hyperthermia in combined treatment of cancer. Lancet Oncol. 2002;3(8):487-497.

\section{Publish your work in this journal}

The International Journal of Nanomedicine is an international, peerreviewed journal focusing on the application of nanotechnology in diagnostics, therapeutics, and drug delivery systems throughout the biomedical field. This journal is indexed on PubMed Central, MedLine, CAS, SciSearch $\AA$, Current Contents ${ }^{\circledR} /$ Clinical Medicine,
Journal Citation Reports/Science Edition, EMBase, Scopus and the Elsevier Bibliographic databases. The manuscript management system is completely online and includes a very quick and fair peer-review system, which is all easy to use. Visit http://www.dovepress.com/ testimonials.php to read real quotes from published authors. 